\title{
CYSTITIS CYSTICA - CHRONIC URINARY BLADDER INFLAMMATION IN CHILDREN
}

\section{PRZEWLEKŁE ZAPALENIE PĘCHERZA MOCZOWEGO TYPU CYSTITIS CYSTICA U DZIECI}

\author{
Magdalena Szymanek-Szwed ${ }^{1(\mathrm{~A}, \mathrm{~B}, \mathrm{C}, \mathrm{D}, \mathrm{E}, \mathrm{F})}$, Beata Jurkiewicz $^{1(\mathrm{~A}, \mathrm{D}, \mathrm{F})}$, \\ Joanna Samotyjek ${ }^{1(C, D, E, F)}$, Katarzyna Załęska-Oracka ${ }^{1(A, B, C, D)}$
}

${ }^{1}$ Department of Pediatric Surgery and Pediatric Urology, Medical Centre of Postgraduate Education, Warsaw, Poland

Authors' contribution Wkład autorów:

A. Study design/planning zaplanowanie badań B. Data collection/entry zebranie danych C. Data analysis/statistics dane - analiza i statystyki D. Data interpretation interpretacja danych E. Preparation of manuscript przygotowanie artykułu F. Literature analysis/search wyszukiwanie i analiza literatury G. Funds collection zebranie funduszy

\begin{abstract}
Summary
Background. Infections of the urinary tract are the second most common bacterial infections occurring among the pediatric population. Cystitis cystica is the prevalent form of chronic inflammation which occurs in children. The pathogenesis of the disease is unclear, however recurrent urinary tract infections are considered to be the most common cause. Inflammation may be asymptomatic or present with symptoms of active infection. Chronic inflammation can lead to micturition disorders. Treatment of cystitis cystica is difficult and long-lasting. Here, the authors present their experience on the diagnosis and treatment of patients with cystitis cystica.

Material and methods. In the period 2016-2019, 871 cystoscopies were performed at the Department of Pediatric Surgery and Pediatric Urology of the Centre of Postgraduate Medical Education, Warsaw, Poland. Depending on the severity of macroscopic changes, the severity of symptoms, and the occurrence of recurrent urinary tract infections, different treatment protocols were used: oral administration of furazidine and trimethoprim with sulfamethoxazole, intravesical instillation of gentamicin and immunomodulating treatment in chosen cases.

Results. Improvement in the clinical condition of sick children was achieved in $79 \%$ of patients $(84 / 106)$. Changes in endoscopic findings did not always correlate with clinical symptoms. Conclusions. The authors recommend extended diagnostics to include endoscopic examination in children with recurrent bladder infections and/or voiding disorders that are difficult to treat. This will allow exclusion or diagnosis of cystitis cystica and enable appropriate treatment at the initial stage of the disease, making regression of the changes in the bladder mucosa possible with oral pharmacotherapy only.
\end{abstract}

Keywords: cystitis, chronic cystitis, cystitis cystica, voiding disorders, recurrent urinary tract infections

\section{Streszczenie}

Wprowadzenie. Zakażenia układu moczowego zajmuja drugie miejsce wśród wszystkich infekcji bakteryjnych w populacji dziecięcej. Cystitis cystica jest najczęstszą formą przewlekłego zapalenia pęcherza moczowego u dzieci. Patogeneza choroby jest niejasna, jednakże uważa się, że najczęstszą przyczyną są nawracające zakażenia układu moczowego. Zapalenie może być bezobjawowe lub przebiegać w formie aktywnej infekcji i wywoływać zaburzenia mikcji. Leczenie zmian o typie cystitis cystica jest trudne i długotrwałe. Autorzy przedstawiają własne doświadczenia dotyczące diagnostyki i leczenia pacjentów z cystitis cystica.

Materiał i metody. W latach 2016-2019 w Klinice Chirurgii Dziecięcej i Urologii Dziecięcej Centrum Medycznego Kształcenia Podyplomowego w Warszawie wykonano 871 cystoskopii. W zależności od stopnia nasilenia zmian makroskopowych, nasilenia dolegliwości, oraz występowania nawracających zakażeń układu moczowego, stosowano różne protokoły leczenia obejmujace leczenie doustne furazydyną i trimetoprimem z sulfametoksazolem, leczenie miejscowe wlewkami dopęcherzowymi gentamycyny, oraz leczenie immunomodulujące u wybranych pacjentów.

Wyniki. Poprawę stanu klinicznego chorych dzieci uzyskano u 79\% pacjentów (84/106). Zmiany w obrazie endoskopowym nie zawsze korelowały z objawami klinicznymi.

Wnioski. Autorzy uważają za celowe poszerzenie diagnostyki u pacjentów z nawracającymi zakażeniami pęcherza moczowego i/lub zaburzeniami mikcji trudno poddającymi się leczeniu, o badania endoskopowe. Pozwolą one wykluczyć bądź rozpoznać cystitis cystica i włączyć odpowiednie leczenie w początkowym okresie choroby, umożliwiając regresję zmian błony śluzowej pęcherza moczowego przy zastosowaniu jedynie farmakoterapii doustnej.

Słowa kluczowe: zapalenie pęcherza moczowego, przewlekłe zapalenie pęcherza moczowego, cystitis cystica, zaburzenia mikcji, nawracające zakażenia układu moczowego
Tables: 3

Figures: 4

References: 19

Submitted: 2020 Oct 23

Accepted: 2021 Jan 26

Szymanek-Szwed M, Jurkiewicz B, Samotyjek J, Załęska-Oracka K. Cystitis cystica - chronic urinary bladder inflammation in children. Health Prob Civil. 2021; 15(1): 61-67. https://doi.org/10.5114/hpc.2021.103356

Address for correspondence / Adres korespondencyjny: Magdalena Szymanek-Szwed, Department of Pediatric Surgery and Pediatric Urology, Medical Centre of Postgraduate Education, Marymoncka 99/103, 01-813 Warsaw, Poland, e-mail: magdalena.szwed@szpitaldziekanow.pl, phone: +48 22 5693 700

ORCID: Magdalena Szymanek-Szwed https://orcid.org/0000-0003-4307-4731, Beata Jurkiewicz https://orcid.org/0000-0001-5112-3316

Joanna Samotyjek https://orcid.org/0000-0002-3955-6685, Katarzyna Załęska-Oracka https://orcid.org/0000-0003-2768-3393

Copyright: (C) Pope John Paul II State School of Higher Education in Biała Podlaska, Magdalena Szymanek-Szwed, Beata Jurkiewicz, Joanna Samotyjek, Katarzyna Załęska-Oracka. This is an Open Access journal, all articles are distributed under the terms of the Creative Commons Attribution-NonCommercial-ShareAlike 4.0 International (CC BY-NC-SA 4.0) License (http://creativecommons.org/licenses/by-nc-sa/4.0/), allowing third parties to copy and redistribute the material in any medium or format and to remix, transform, and build upon the material, provided the original work is properly cited and states its license. 


\section{Introduction}

Urinary tract infections (UTI) take second place among all bacterial infections in the pediatric population. In infancy, they occur more often in boys, and after the end of the first year of life, the frequency is greater in girls [1]. The most frequently isolated pathogen is Escherichia coli (80-90\% of infections) along with other gramnegative bacteria: Pseudomonas, Klebsiella, Enterobacter, and others, the source of which are the gastrointestinal tract, vaginal vestibule, and narrowed foreskin in the case of phimosis [1]. Anatomical defects and dysfunction of the lower urinary tract such as posterior urethral valves, vesicoureteral reflux, urolithiasis, neurogenic bladder dysfunction and phimosis, as well as constipation, poor hygiene habits, urinary retention, insufficient fluid supply, are factors which favor development of UTI [1,2].

Acute cystitis manifests with bacteriuria, leukocyturia, erythrocyturia or hematuria, foul-smelling urine, urinary urgency, increased daytime urinary frequency, painful urination, and fever [3]. An ultrasound scan often shows a thickening of the bladder wall [4]. Recurrent urinary tract infections lead to chronic inflammation of the bladder. Symptoms of cystitis lasting longer than 2-3 weeks or recurrence of infection appearing after a short period of remission may suggest chronic cystitis $[1,5,6]$.

The most common form of chronic cystitis in children is cystitis cystica, diagnosed in approximately $10 \%$ of patients with UTI [1,7], with an 80\% female predominance [8]. Endoscopic examination of the lower urinary tract shows small, pearly, pink, brown, or yellow cysts within the mucosa. Lesions are most often located within the triangle of the bladder, neck and around the ureteric orifices [9], less frequently they cover the entire surface of the bladder, and are exceptionally described in the ureters and pelvis [10] (Figures 1-3).

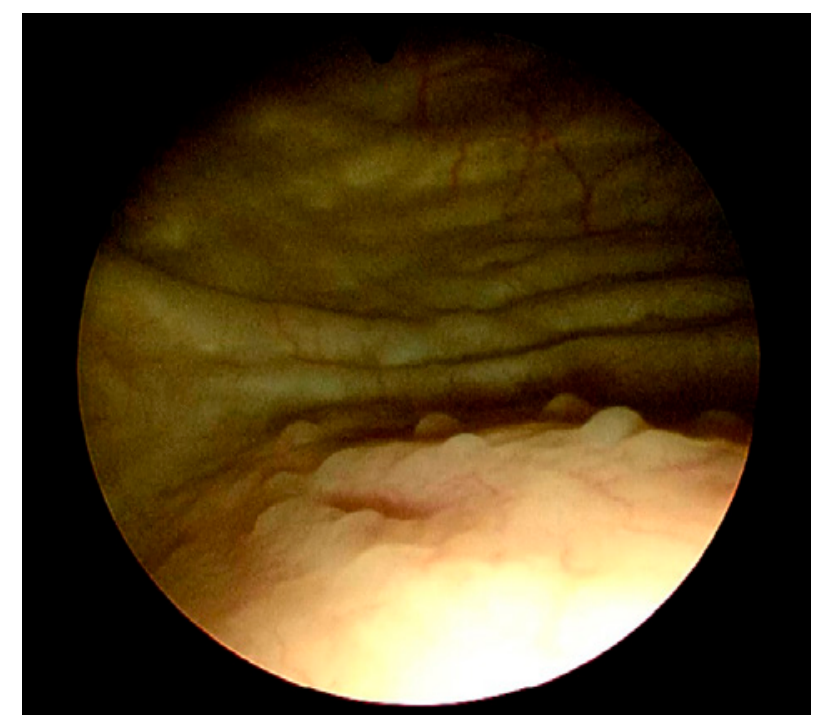

Figure 1. Cystitis cystica - endoscopic view

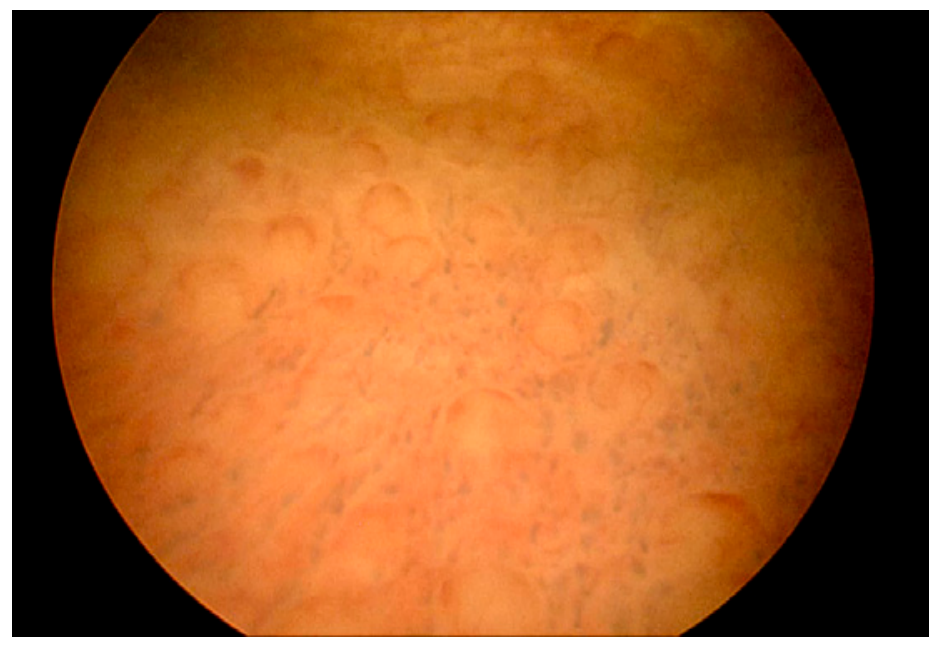

Figure 2. Cystitis cystica - endoscopic view 


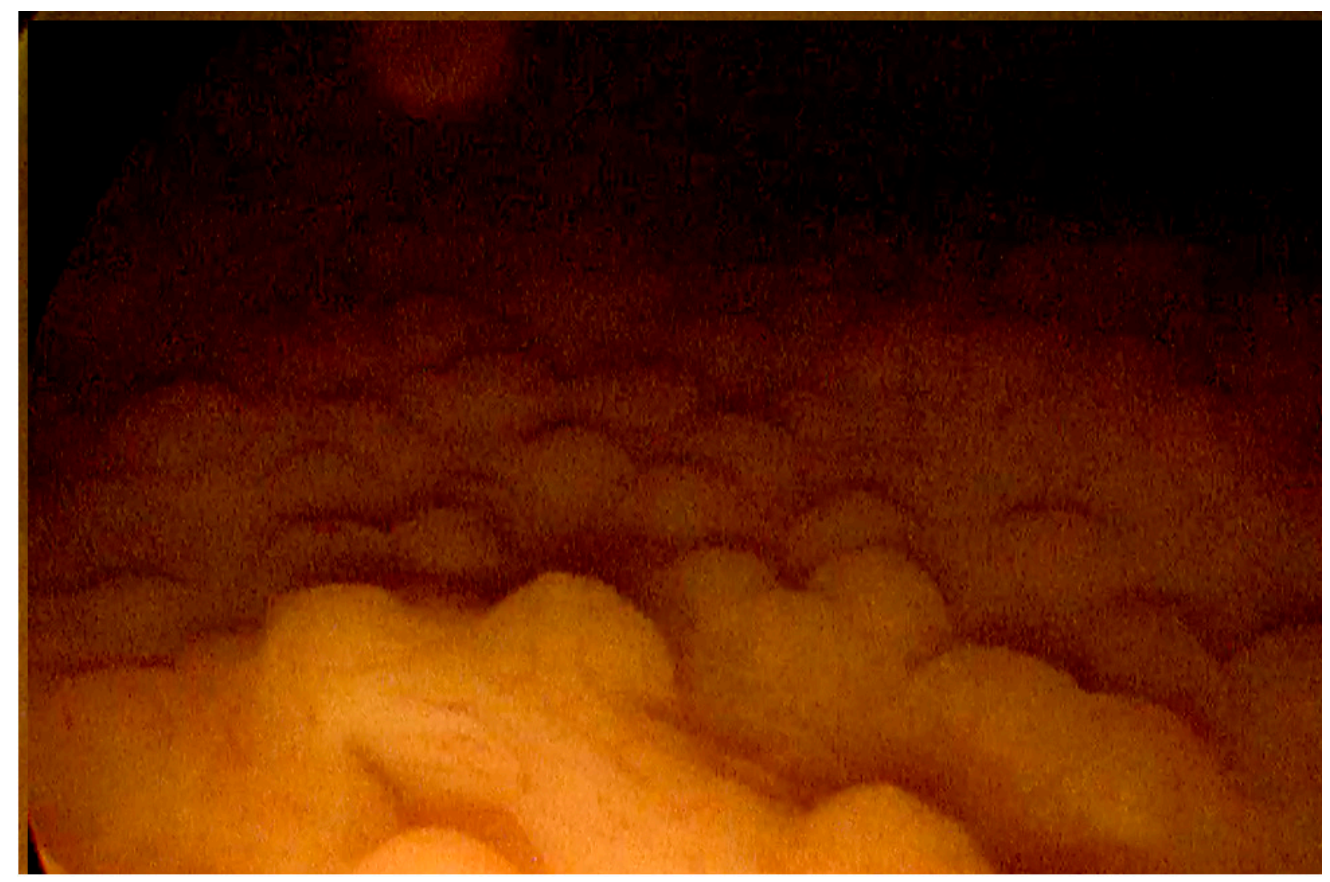

Figure 3. Cystitis cystica - endoscopic view

At endoscopic examination, cystitis cystica may be accompanied by trabeculation of the bladder wall, and swelling and congestion of the mucosa. In some patients, these changes are absent at first examination and only appear at subsequent cystoscopies [11].

The pathogenesis of cystitis cystica is unclear. The changes originate from the urothelial buds, which tuck into the submucosa and form the so-called Brunn's nests within the lamina propria, which then degenerate into a cystic form with the appearance of luminal mucin $[2,5,8]$. They do not penetrate the muscularis propria of the urinary bladder [7]. According to one hypothesis, this is due to a type of local immune reaction with excessive IgA secretion [5].

In patients over 18 years of age, cystitis cystica is considered a precancerous condition [1,2,6,9]. Microscopic examination of specimens taken from altered mucosa shows reactive atypia of urothelial cells, hyperplasia, dysplasia and carcinoma in situ. However, neoplastic epithelial changes have not been observed in children [1].

Clinically, inflammation may be asymptomatic or manifest with symptoms of active infection. Chronic inflammation may lead to urinary incontinence, urgency, increased daytime urinary frequency, dysuria, and even urinary retention $[2,3,5,6,8,9,11]$. Detrusor overactivity, reduction in urinary flow rate, irregular patterns of urine flow and residual urine after voiding which further predisposes to infection, may be found in urodynamic tests $[3,5]$. Imaging examinations such as ultrasound (US) and computed tomography (CT) show thickening of the bladder wall $[4,9]$.

Treatment of cystitis cystica is difficult and long-lasting. Alternating treatment with oral furazidine and trimethoprim with sulfamethoxazole, and intravesical infusions of antibiotics (gentamicin) and corticosteroids (prednisone) are often used [1,5,8,12].

The authors present their experience in the diagnosis and treatment of patients with cystitis cystica. The aim of the study was to analyze the population of patients treated at the authors' center.

\section{Material and methods}

From 2016 to 2019, 871 cystoscopies were performed at the Department of Pediatric Surgery and Pediatric Urology of the Centre of Postgraduate Medical Education, Warsaw, Poland.

The indications for cystoscopy were:

- recurrent UTI,

- micturition disorders,

- defects of the urinary system,

- combinations of the above. 
Based on the severity of lesions found during endoscopic examination, patients were divided into three groups: those with single vesicles within the bladder mucosa (group I), those with vesicles limited to the bladder triangle (group II) and those with extensive changes covering the entire bladder mucosa (group III).

Depending on the severity of macroscopic changes, the severity of symptoms and the occurrence of recurrent UTI, the following treatment protocols were used:

- Group I (single lesions, mild inflammation) - oral furazidine/trimethoprim + sulfamethoxazole for 7-10 days;

- Group II (severe lesions) - oral alternating treatment with furazidine/trimethoprim + sulfamethoxazole for at least 3 months, with change of drug every week;

- Group III (very severe lesions) - alternating treatment with furazidine/trimethoprim + sulfamethoxazole + gentamicin/ hydrocortisone intravesical infusions +/- immunomodulating treatment (Thym-Uvocal, Uro-Vaxom, vitamin A, Psudovac, D-mannose).

Furazidine was administered at a dose of 5-7 mg/kg of body weight/day in 2-3 divided doses. Trimethoprim + sulfamethoxazole was administered at a dose of $36 \mathrm{mg} / \mathrm{kg}$ of body weight/day in 2 divided doses. Intravesical infusions were administered twice a day for 10 days, then once a day for 20 days. The dose of gentamicin used was 40-80 mg in 50-100 mL 0.9\% NaCl with hydrocortisone $50 \mathrm{mg}$ in $50 \mathrm{~mL} 0.9 \% \mathrm{NaCl}$.

Depending on the severity of lesions and symptoms, one or more bladder infusion cycles were performed at monthly intervals. Children with lower urinary tract symptoms (LUTS), determined based on urodynamic tests, also received drugs influencing bladder function e.g. oxybutynin, solifenacin or doxazosin. The children were treated and followed for one year in accordance with the developed treatment protocol, depending on the severity of changes observed during the first endoscopic examination.

\section{Results}

Cystitis cystica was found in 106 patients with an age range of 6 months to 18 years, and a median age of 8.57 years. Girls made up 89.6\% of the population (95 patients), and 10.4\% (11 patients) were boys (Figure 4).

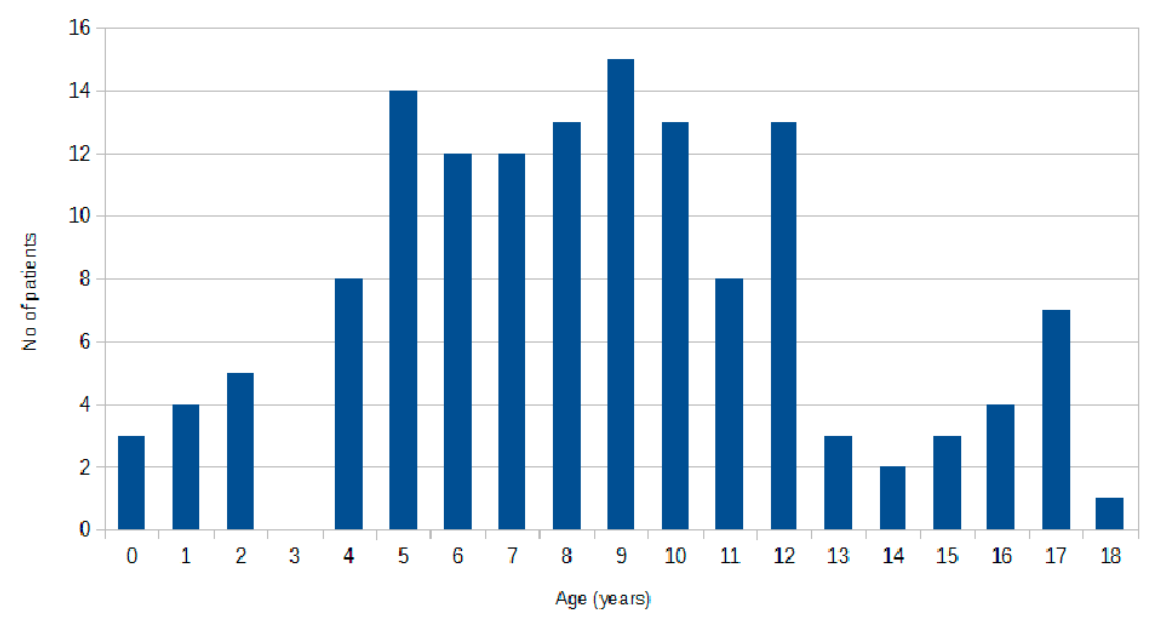

Figure 4. Number of patients according to age

Recurrent UTI occurred in 69 (65\%) patients with cystitis cystica, 3 patients (3\%) had only one UTI episode, and $34(32 \%)$ had no infections (Table 1).

Table 1. Urinary tract infections

\begin{tabular}{|c|c|}
\hline Urinary tract infections (UTI) & Number of patients \\
\hline No UTI & $34(32 \%)$ \\
\hline Single UTI & $3(3 \%)$ \\
\hline Recurrent UTI & $69(65 \%)$ \\
\hline
\end{tabular}

Voiding disorders were found in 55 (52\%) patients: nocturnal enuresis occurred in 45 (43\%), urinary incontinence in 39 (37\%), urgency in 19 (18\%), and other disorders such as dysuria and increased daytime urinary frequency in 7 (7\%) (Table 2). 
Table 2. Micturition disorders

\begin{tabular}{|c|c|}
\hline Micturition disorders & Number of patients \\
\hline Nocturnal enuresis & $45(43 \%)$ \\
\hline Urinary incontinence & $39(37 \%)$ \\
\hline Urgency & $19(18 \%)$ \\
\hline Dysuria, increased daytime urinary frequency and other & $7(7 \%)$ \\
\hline None & $51(48 \%)$ \\
\hline
\end{tabular}

Urodynamic examination was performed in all patients with LUTS. Detrusor overactivity and reduced bladder volume were found in all patients.

Coexisting defects were found in 38 patients: vesicoureteral reflux in 23, neurogenic bladder dysfunction in 7 (including after myelomeningocele surgery in 4), and posterior urethral valves in 8/11 boys. Constipation and encopresis occurred in 9 patients.

Based on the severity of lesions found in endoscopic examination, patients were divided into three groups (Table 3):

- Group I: 46 patients,

- Group II: 18 patients,

- Group III: 42 patients.

Table 3. Severity of lesions

\begin{tabular}{|c|c|}
\hline Severity of lesions & Number of patients \\
\hline Single vesicles & 46 \\
\hline Lesions limited to the bladder triangle & 18 \\
\hline Extensive lesions & 42 \\
\hline
\end{tabular}

In 22 patients, coexistence of squamous cell metaplasia of the urinary bladder was found (either as changes found during the first cystoscopy or changes which appeared during treatment). Patients in group I did not undergo a routine control cystoscopy.

In group II, the criteria for the endoscopic examination was the persistence of symptoms despite treatment (6/18 patients). In group III, a control cystoscopy was performed in all patients after about 6 months. Control cystoscopy was not performed in 58 patients due to clinical improvement within a year, i.e. no signs of UTI and disappearance of symptoms. Bladder detrusor overactivity characteristics decreased in this group of patients and there were no recurrences of infection for a year. Endoscopic examination was performed in patients from group II who did not achieve a satisfactory improvement, and in all patients from group III.

The 48 control cystoscopies showed:

- in 22 patients: a significant improvement in the endoscopic findings (either no or single vesicles) was observed. In this group, no UTI occurred and micturition disorders resolved in $30 \%$ of patients;

- in 12 patients: the endoscopic findings revealed less severe lesions, including 2 without UTI;

- in 9 patients the endoscopic findings did not change (this group included 2 children who did not develop UTI, and 1 whose micturition disorders resolved);

- in 5 cases: the lesions intensified despite treatment and no clinical improvement was observed.

Overall, improvement in the clinical condition of sick children and the symptoms of dysuria was achieved in $84 / 106$, i.e. $79 \%$ patients. Changes in endoscopic findings did not always correlate with clinical symptoms.

\section{Discussion}

Cystitis cystica is the most common form of chronic cystitis diagnosed in children [1]. Chronic or recurrent infections cause an excessive IgA-mediated inflammatory reaction in the mucosa. The intensified inflammatory process results in micturition disorders, which are often very troublesome and exclude the child from everyday activities. Treatment of cystitis cystica is difficult and long-lasting. Oral administration of furazidine and trimethoprim with sulfamethoxazole, and local treatment with intravesical infusions of antibiotics (gentamicin) and corticosteroids (prednisone) are used [1,2,5,6,8,12].

The available literature is scarce regarding cystitis cystica in the pediatric population. Most articles dealing with this subject examine an adult population. In recent years, there have been reports appearing of the effectiveness of intravesical administration of hyaluronic acid, which, by covering the urothelial epithelium, blocks the penetration of irritants such as bacteria, deposits or components of urine. It also stimulates the 
production of endogenous glycosaminoglycans, which form a natural protective barrier $[2,6,12]$. Yongliang $\mathrm{Ni}$ presented an encouraging model of treatment using application of intravesicular sodium hyaluronate [2]. The described therapy significantly improved the clinical symptoms of patients with cystitis cystica, and moreover decreased bladder mucosal inflammation and cell proliferation characteristics of the disease. However, it should be emphasized that the studied group were adults 42-61 years old. Several papers have been published with similar conclusions [12-14] however there are no studies to date on the pediatric population considering intravesical sodium hyaluronate.

In 2010, Milosević published a study of 127 cases of endoscopically confirmed cystitis cystica in children with a mean age of 6.1 years. All patients were treated with sulfamethoxazole/trimethoprim or nitrofurantoin for at least one year. The median duration of chemoprophylaxis was 2.5 years. Patients were categorized into three groups according to number of nodular changes in bladder mucosa [15]. The results depended on the severity of the lesions in the bladder, and presence of full recovery, defined as no recurrence of UTI for one year after the end of treatment, which was achieved in $48 \%$ of patients, however only in cases of lesions of small and medium intensity (5-10 vesicles) [5,15].

Milosević et al. also demonstrate correlation between severity of the disease and outcome of treatment. It is suggested that the intensity of cystitis cystica can be a good prognostic factor for evolution of the disease [15]. In the present author's study, patients were also divided into 3 groups depending on the severity of the lesions. Contrary to Milosević, in 22 control cystoscopies a significant improvement in endoscopic finding was observed. Moreover, in 12 children, control cystoscopy revealed less severe lesions. However, comparing these two studies is difficult because the methodology used in them was different and patients received different treatment. In the present author's group, children with urinary tract anomalies were not excluded. Furthermore, therapy was more intensive because intravesical treatment was used alongside oral therapy.

The persistence of follicular lesions was also found by Hansson in girls with persistent bacteriuria, and their resolution was confirmed when bacteriuria was eliminated [7]. Similar conclusions were published by Vuckov et al. who analyzed the relationship between UTI treatment and the disappearance of cystitis cystica lesions in a group of 47 patients with a mean age of 7.35 years. In $44.3 \%$ of children, changes disappeared after one year of treatment, whereas in 6 patients, more than 5 years were required to achieve complete resolution of cystitis cystica [16]. Asklin describes the case of a patient with a 2 year history of severe cystitis with painful urination, urinary urgency and urinary incontinence, in whom a lasting anti-inflammatory effect was achieved using repeated lidocaine infusions [17].

In the material presented by the authors, clinical improvement was achieved in $79 \%$ of patients, and in $54 \%$ the improvement was so significant that they did not require another cystoscopy. In some of the remaining patients, even though the endoscopic picture did not improve, symptoms and signs of UTI had receded. The small percentage of patients who did not respond positively to any form of treatment remain a challenge. In this group, immunomodulatory treatment and the search for new therapeutic solutions seem to be of greatest importance [18,19].

\section{Conclusions}

So far, no uniform guidelines have been developed regarding the management of children with cystitis cystica. Diagnosis of UTI, especially in early childhood, can be difficult due to the lack of specific symptoms. It is advisable to extend diagnostics to include endoscopic examination in patients with recurrent bladder infections +/- voiding disorders that are difficult to treat to exclude or diagnose cystitis cystica and enable appropriate treatment in the initial stage of the disease. Early diagnosis allows faster regression of changes in the bladder mucosa using oral pharmacotherapy only, gives a greater chance of the symptoms subsiding, and avoids the need for bladder irrigation, which is often difficult to accept for pediatric patients.

\section{Disclosures and acknowledgements}

Results of this study were presented as an oral presentation at European Academy of Pediatrics, Porto, Portugal, 2019.

\section{References:}

1. Muszyńska J, Goszczyk A, Jurkiewicz B, Samotyjek J. Recurrent urinary tract infections connected with cystitis cystica. Pediatria i Medycyna Rodzinna. 2007; 3(3):177-181. 
2. Ni Y, Zhao S, Yin X, Wang H, Guang Q, Hu G, et al. Intravesicular administration of sodium hyaluronate ameliorates the inflammation and cell proliferation of cystitis cystica et glandularis involving interleukin-6/ JAK2/Stat3 signaling pathway. Scientific reports. 2017; 7: 15892. https://doi.org/10.1038/s41598-017-16088-9

3. Bo K, Frawley HC, Haylen BT, Abramov Y, Almeida FG, Berghmans B, et al. The International Continence Society (ICS) report on the terminology for adult male lower urinary tract and pelvic floor symptoms and dysfunction. Neurourol Urodyn. 2019; 38(2): 433-477.

4. Vrljicak K, Milosević D, Batinić D, Kniewald H, Nizić L. The significance of ultrasonography in diagnosing and follow-up of cystic cystitis in children. Coll Antropol. 2006; 30(2): 355-359.

5. Piechuta L, Kalicka K, Sikora P. [Urodynamic findings in squamous metaplasia of bladder mucosa and cystitis cystica in children]. Ann. Acad. Med. Siles. 2017; 71: 393-398 (in Polish). https://doi.org/10.18794/aams/70335

6. Raymond I, Vasdev N, Fergusson J, Haskin M, Davis L, Tasheen SH. The clinical effectiveness of intravesical sodium haluronate (cystistat) in patients with interstitial cystitis/painful bladder syndrome and recurrent urinary tract infections. Current Urology. 2012; 6: 93-98. https://doi.org/10.1159/000343517

7. Hansson S, Hanson E, Hjälmås K, Hultengren M, Jodal U, Olling S, et al. Follicular cystitis in girls with untreated asymptomatic or covert bacteriuria. The Journal of Urology. 1990; 143(2): 330-332. https://doi.org/10.1016/S0022-5347(17)39950-0

8. Basianpillai C, Warner R, Beltran L, Green J. Cystitis cystica and glandularis producing large bladder masses in a 16-year-old boy. Journal of the Royal Society of Medicine Open. 2018; 9(3): 1-3.

https://doi.org/10.1177/2054270417746060

9. Sochaj M. [Cystitis cystica]. Przegląd Urologiczny. 2016; 95(1): 20-21 (in Polish).

10. Belman AB. The clinical significant of cystitis cystica in girls: results of a prospective study. J Urol. 1978; 119(5): 661-663. https://doi.org/10.1016/S0022-5347(17)57582-5

11. Vlatković G, Bradić I, Gabrić V, Batinic D. Cystitis cystica. Characteristics of the disease in children. British Journal of Urology. 1997; 49: 57-59. https://doi.org/10.1111/j.1464-410X.1977.tb04523.x

12. Lazzerati M, Hurle R, Casale P, Buffi M, Lughezzani G, Fiorini G, et al. Managing chronic bladder diseases with the administration of exogenous glycosaminoglycans: an update on the evidence. Ther Adv Urol. 2016; 8(2): 91-99. https://doi.org/10.1177/1756287215621234

13. Wyndaele JJJ, Riedl C, Taneja R, Lovász S, Ueda T, Cervigni M. GAG replenishment therapy for bladder pain syndrome/interstitial cystitis. Neurourol Urodyn. 2019; 38(2): 535-544. https://doi.org/10.1002/nau.23900

14. Rooney P, Srivastava A, Watson L, Quinlan LR, Pandit A. Hyaluronic acid decreases IL-6 and IL-8 secretion and permeability in an inflammatory model of interstitial cystitis. Acta Biomater. 2015; 19: 66-75. https://doi.org/10.1016/j.actbio.2015.02.030

15. Milosević D, Batinić D, Tesović G, Konjevoda P, Kniewald H, Subat-Dezulović M. Cystitis cystica and recurrent urinary tract infections in children. Coll Antropol. 2010; 34(3): 893-897.

16. Vuckov S, Subat-Dezulović M, Nikoloć H. Relation between successful treatment of urinary tract inflammation and the disappearance of changes in the bladder mucosa in children and adolescents with cystoscopically proven cystitis cystica. Lijec Vjesn. 1997; 119(10): 266-269.

17. Asklin B, Cassuto J. Intravesical lidocaine in severe interstitial cystitis - case report. Scandinavian Journal of Urology and Nephrology. 1989; 23(4): 311-312. https://doi.org/10.3109/00365598909180345

18. Prokurat S. [Urinary tract infection in children]. Pediatria interdyscyplinarna. 2015; 6 (in Polish).

19. Żurowska A, Wasilewska A, Jung A, Kiliś-Pstrusińska K, Pańczyk-Tomaszewska M, Sikora P, et al. [Recommendations of the Polish Society of Pediatric Nephrology regarding the treatment of a child with urinary tract infection]. Forum Medycyny Rodzinnej. 2016; 10(4): 159-178 (in Polish). 